\title{
Research on the Influencing Factors and Paths of Non-performing Loan Ratio of Rural Commercial Banks in China
}

\author{
Qualitative Research and Investigation Based on Grounded Theory
}

\author{
Minghui Jiang \\ School of Management \\ Harbin Institute of Technology \\ Harbin, China 150000
}

\author{
Xin'ge Zhang \\ School of Management \\ Harbin Institute of Technology \\ Harbin, China 150000
}

\begin{abstract}
As a unique commercial bank in China, rural commercial banks play an important role in implementing policies on agriculture, rural areas and farmers and narrowing the urban-rural gap. However, its non-performing loan ratio is much higher than the average level of commercial banks, which seriously affects the timely and correct performance of rural commercial banks' functions. This paper adopts the qualitative research method of grounded theory, collects original data through in-depth interviews, forms concepts, categories and core concept categories through three-level coding, and obtains the influencing factors and paths of nonperforming loan ratio of rural commercial banks. First, macroeconomic condition, source structure of loan repayment fund for peasant households, income level and labor force destination are all economic factors affecting the loan repayment ability of customers of rural commercial banks, thus affecting the non-performing loans of rural commercial banks. Second, personnel setting, capital reserve and profitability of the banks all affect the lending capacity of rural commercial banks as internal factors, thus affecting the nonperforming loan ratio of agricultural commercial bank. And
\end{abstract}

third, some external interference factors such as: natural or man-made emergencies may irregularly and unexpectedly interfere with the normal recovery of loans of rural commercial banks, thus affecting the non-performing loan ratio of rural commercial banks.

Keywords-rural commercial bank; non-performing loan ratio; qualitative research; Grounded theory; in-depth interviews

\section{INTRODUCTION}

With the development of China's economy and society and the promotion of policies on agriculture, rural areas and farmers, rural commercial banks have been gradually established and organized, and become the backbone of rural financial institutions that will replace rural credit cooperatives and rural cooperative banks, and the main force in handling agriculture-related loans and assisting agriculture, rural areas and farmers. By the end of 2016, there were 1,055 rural and commercial banks nationwide. The distribution of them in each province is shown in "Table I":

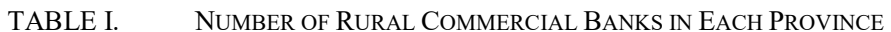

\begin{tabular}{|l|l|l|l|l|l|l|l|}
\hline \multicolumn{1}{|c|}{ Region } & Number & \multicolumn{1}{|c|}{ Region } & Number & \multicolumn{1}{|c|}{ Region } & \multicolumn{1}{|c|}{ Number } & \multicolumn{1}{c|}{ Region } & Number \\
\hline $\begin{array}{l}\text { Eastern } \\
\text { China }\end{array}$ & 314 & $\begin{array}{l}\text { Middle- } \\
\text { China }\end{array}$ & 422 & $\begin{array}{l}\text { western } \\
\text { China }\end{array}$ & 234 & $\begin{array}{l}\text { Northeast } \\
\text { China }\end{array}$ & 85 \\
\hline Jiangsu & 62 & Anhui & 83 & Sichuan & 46 & Jilin & 32 \\
\hline Guangdong & 33 & Hubei & 77 & Chongqing & 1 & Liaoning & 22 \\
\hline Shandong & 107 & Hunan & 93 & Shaanxi & 48 & Heilongjiang & 31 \\
\hline Zhejiang & 51 & Henan & 56 & Guizhou & 38 & & \\
\hline Beijing & 1 & Jiangxi & 69 & $\begin{array}{l}\text { Inner } \\
\text { Mongolia }\end{array}$ & 23 & & \\
\hline Shanghai & 1 & Shanxi & 44 & Gansu & 23 & & \\
\hline Tianjin & 2 & & & Xinjiang & 10 & & \\
\hline Fujian & 20 & & & Guangxi & 26 & & \\
\hline Hebei & 32 & & & Ningxia & 9 & & \\
\hline
\end{tabular}


However, according to a report from business.sohu.com/ on February 2017 that the non-performing loan ratio of China's rural commercial banks was $2.5 \%$, about 0.7 percentage points higher than the average level of commercial banks. The high non-performing loan ratio seriously affects the normal operation and lending capacity of rural and commercial banks, and even affects the implementation of policies on agriculture, rural areas and farmers, as well as the living standard of farmers and rural and agricultural development. Therefore, investigating the factors influencing the non-performing loan ratio of rural commercial banks plays an important role and significance in finding ways to reduce the non-performing loan ratio of rural commercial banks, promoting the implementation of policies on agriculture, rural areas and farmers, promoting the development of modern agriculture and stabilizing rural society.

As agricultural commercial bank is a special commercial bank with Chinese characteristics, most of the research on it is concentrated in China. At the same time, it wasn't until 2000 that the rural commercial bank was established, the domestic research on it is not quite satisfactory. However, in terms of research methods, mature research methods and indicator systems for the non-performing loan ratio of general commercial banks have been applied abroad, which are not completely applicable to the research of China's special commercial banks - rural commercial banks. However, most domestic researches focus on the investigation of general macroeconomic factors and ignore the characteristics of rural commercial banks. Therefore, the method of qualitative research and grounded theory is selected to obtain primary data from the population closely related to rural commercial banks, and the influencing factors and paths gained in the process can make the conclusion more consistent with the characteristics of rural commercial banks and the suggestions more targeted.

\section{LITERATURE REVIEW}

Since rural commercial banks are a kind of special commercial banks in China, there are both similarities and differences between rural commercial banks and general commercial banks.

However, in the relevant researches at home and abroad, the investigation on the factors influencing the nonperforming loan ratio of general commercial banks has been relatively mature and gradually formed a system. Scholars at home and abroad have found that macroeconomic factors such as GDP and its growth rate, unemployment rate or employment level, income level or wage level, bank interest rate and other macroeconomic factors have a significant impact on the non-performing loan rate of general commercial banks. For example, Brookes M, Dicks M and Pradhan M (1994) found that unemployment rate and interest rate can significantly affect non-performing loans when they studied the empirical model of mortgage delinquency and recovery [1]; Lopes P (2008) proved in his study that labor income is directly related to default: as unemployment increases, borrowers with lower income levels are at higher risk of default [2]; Demirguckunt A, Detragiache E (2016) proposed in their paper that GDP growth rate, unemployment, bank interest rate and moral hazard may affect the credit risk of banks and even lead to bank crisis [3]. Chinese scholars also tend to investigate macro factors when conducting relevant researches: Xie Haidong and Hao Yibo (2017) proved that from the perspective of long-term dynamic trends, GDP growth rate and market interest rate affect nonperforming loans of commercial banks [5]. Zhang Xiaoxi (2017) also proved that year-on-year GDP growth affects the non-performing loan ratio of banks by using the panel data model [6]. Zhuo Mingying (2011) also confirmed in his research that GDP growth rate and inflation rate have an impact on the non-performing loan ratio of commercial banks [7]. Wang Guangwei and Tong Yuansong (2014) also proved that GDP growth rate has an impact on the nonperforming loan ratio of commercial banks [8].

At the same time, domestic and foreign scholars have found that internal factors of banks, such as cost efficiency, bank capital and bank scale, also have a significant impact on the non-performing loan ratio of commercial banks: For example, Berger A N and Deyoung R (1997) proved that loan quality, cost efficiency and bank capital have an impact on non-performing loans [9]. Podpiera J and Weill L (2008) also investigated the causal relationship between nonperforming loans and cost efficiency [10]. Belaid F (2014) also came to the conclusion that banks with low cost, less capital, diversification and miniaturization are more likely to produce non-performing loan portfolios [11]. Stolz $\mathrm{S}$ and Wedow M (2011) [12] J Ayuso, D Perez, J Saurina (2004) [13] et al. proved the negative correlation between capital adequacy and non-performing loans through empirical research, while Lindquist G (2004) [14] proved the positive correlation between capital adequacy and bank risk. In addition, studies by Xu Hui, Li Jian, Zhong Huibo et al. (2013) proved that the cost efficiency of banks has an impact on their non-performing loan ratio [15]. And Fan Yong also found that internal factors such as bank size and loan-todeposit ratio affect the non-performing loan ratio when he studied the factors influencing the non-performing loan ratio of commercial banks.

However, as rural commercial banks and rural credit cooperatives (which will be established as rural commercial banks after completion of development, so the authors also looks them up for reference in the literature review) are types of banks with Chinese characteristics, domestic researches for this part of is far more than that of foreign banks. After reviewing relevant literatures in the past five years, it is found that researches on non-performing loans of rural commercial banks also pay more attention to external factors such as GDP and regional economic development level. Studies of Chen Weiping, Feng Zongxian (2015) [17], Li Jing, Zhu Chengliang and Zheng Shilin (2016) [18] for example, all have this feature.

In terms of research methods and quantitative investigation, Li Jing (2014) et al. have adopted the SBMUndesirable model and Malmquist-luenberger productivity index to investigate; Huang Huichun (2014) et al have also adopted SBM-Undesirable model to measure and decompose, and investigate influencing factors based on panel data 
model [19]; Geng Rui et al. (2014) adopted the time series model [20]; Chen Weiping et al. (2015) used the method of constructing the global malmquist-luenberger productivity index and conducting the convergence test in their study [23]; Li Qing (2016) used DEA model and Tobit regression model in her research [21]; and Cox model method was applied in the study of Ye Chusheng and Zou Xin (2016) [22]. In terms of qualitative investigation, the qualitative investigations on the non-performing loan ratio of rural commercial banks in China mostly take a specific bank as an example to analyze the current situation of the non-performing loan ratio and the problems existing in the bank, so as to speculate the influence of the non-performing loan ratio and give corresponding countermeasures according to the situation of the bank. Such qualitative research is targeted and can draw corresponding countermeasures according to specific bank conditions. However, as it only targets at a certain agricultural commercial bank, the generalization of conclusions and Suggestions is relatively weakened. At the same time, the mechanism of the influencing factors of the non-performing loan ratio of rural commercial banks is also lack of internal logical explanation.

\section{RESEARCH METHODS AND DATA COLLECTION}

\section{A. Research Methods}

When reviewing the literatures, the researchers find that at present, domestic and foreign researches on the factors influencing the non-performing loan ratio mainly focus on the researches on general commercial banks, while the researches on the factors influencing the non-performing loan ratio of rural commercial banks are relatively few. In addition, the indicator system of influencing factors of nonperforming loans of general commercial banks is mostly adopted in the research of quantitative methods, which cannot reflect the characteristics of rural commercial banks. Although the adopting of qualitative methods is targeted, there is a lack of internal logic between mechanism and causation. Therefore, in order to find out the influencing factors of non-performing loan ratio that are more consistent with the particularity of rural commercial banks and explore its influencing mechanism, researchers choose grounded theory and qualitative research as the research method.

Grounded theory and in-depth interview, as qualitative research methods, have been recognized by the academic community as more effective methods for qualitative analysis.

The grounded theory, just as its name implies, emphasize grounding. Before starting this research work, the researchers usually do not make assumptions in advance, but directly obtain first-hand data to explore differences and connections, summarize and summarize, and then abstract theoretical concepts. And as an important tool of qualitative research, in-depth interview method can exactly enable researchers to obtain a large number of primary data. Researchers can interview the corresponding population to obtain the original data, which is more closely related to rural commercial banks and can better reflect the characteristics of rural commercial banks.
Therefore, in this chapter, the researchers refer to the grounded theory analysis method in qualitative research. Through in-depth interviews with bank employees, experts in relevant academic fields and farmers, and hierarchical compilation of open login, associative login and core login, the characteristics of rural commercial banks are obtained. In this way can the more accurate and effective factors influencing the non-performing loan ratio of rural commercial banks be obtained, and thus the influencing mechanism and path can be obtained.

\section{B. Data Collection}

This study intends to reflect the characteristics of rural commercial banks that distinguish them from other commercial banks. Therefore, in terms of the selection of interviewee, the researchers choose the group that is more close to or understand the agricultural commercial bank and divides it into the industry expert group and the customer group of the rural commercial bank. The "snowball" interview method was adopted, that is, in-depth interview and coding were conducted for each object until new categories could not be obtained. In the end, the interviewees include 1 expert and scholar on credit risk of commercial banks, 2 staff members of banks and financial institutions, and 6 farmers as the in-depth interviewees.

\section{RESEARCH PROCESS}

\section{A. Interview Process}

The primary data collection in this chapter is mainly based on in-depth interviews. The researchers conducted indepth interviews with the above-mentioned interviewees and set different interview Outlines for different groups with different emphases. For experts and scholars as well as practitioners of banks and financial institutions, researchers use semi-structured in-depth interviews to deepen their understanding of factors influencing the non-performing loan ratio of rural commercial banks, and set highly structured problems for peasant households who are not good at language expression and other related aspects.

The interview outlines are as follows:

1) The interview outline for experts: Question 1: What do you think are the factors that influence the nonperforming loan ratio of agricultural and commercial bank? Question 2: What do you think is the reason why the nonperforming loan ratio of agricultural commercial bank is higher than the average level of commercial bank?

2) The interview outline for staff of banks and financial institutions:

a) The interview outline for non-rural commercial bank staff: Question 1: What factors do you think affect the non-performing loan ratio of banks and financial institutions? Question 2: Do you know anything about rural commercial bank? If so, please talk about your views on the loan recovery risks faced by rural commercial banks.

b) The interview outline for rural and commercial bank staff: Question 1: what do you think are the 
characteristics of rural commercial banks different from general commercial banks? Question 2: what factors do you think affect the non-performing loan ratio of rural commercial bank?

3) The interview outline for farmer: Question 1: do you currently have a bank loan? What is the purpose of the loan? Why do you choose to borrow money from this bank? Question 2: if you need a loan in the future, would you choose a rural commercial bank (rural credit cooperatives) or another commercial bank (which one?)? Why? Question 3: if you have a loan, which resource do you depend on to repay your loan? (Farming income, wage income or other income (please specify it) Question 4: if you have a loan, which reason do you think will affect your timely repayment? (E.g. crop yields, weather conditions, work, wages, etc.) Question 5: do you think the main reason why the bank can't call in loans is that?

The in-depth interviews focus on the interview outlines, but not limited to the interview outlines. The researchers appropriately adjusted the interview outline and increase or decrease the questions according to the respondents' answers to the questions and the content of the answers. For example, if respondents said that they thought the non-performing loan ratio of agricultural and commercial bank might be related to the bank itself, they would ask about this answer: "what do you mean by the bank's own problem?"

\section{B. Open Login}

First, we made an open coding of the original data obtained from the interview. This part is also called firstorder coding. In this process the researchers broke up the interview record into pieces and name and code it word for word and sentence for sentence to refine the initial concepts and analyze the relations among initial concepts. And then the attributes of each concept were defined and grouped accordingly to achieve categorization. According to the interview record, the researchers obtained 101 original sentences and corresponding initial concepts. After categorizing synonymous concepts and excluding invalid concepts, a total of 20 valid concepts and 10 categories were obtained, as shown in "Table II".

TABLE II. CONCEPTS AND CATEGORIES FORMED BY OPEN CODING

\begin{tabular}{|l|l|}
\hline \multicolumn{1}{|c|}{ Initial concepts } & Categorization \\
\hline Farming accounts for a small proportion of income/farming as a main source of income & $\begin{array}{l}\text { Source structure of loan } \\
\text { repayment funds }\end{array}$ \\
\hline Low wages/poor harvests & Income level \\
\hline Middle-aged people engaged in agriculture/young people engaged in industry or project in cities & Labor force destination \\
\hline $\begin{array}{l}\text { Poor harvests caused by natural disasters/Sudden change in work without pay/Sudden family } \\
\text { changes }\end{array}$ & $\begin{array}{l}\text { Natural or man-made } \\
\text { emergency }\end{array}$ \\
\hline Debt escaping/default/malicious default & $\begin{array}{l}\text { Subjective } \\
\text { to repay }\end{array}$ \\
\hline Poor economillingness \\
\hline $\begin{array}{l}\text { The bank business personnel frequently transfers and the new staff ignores the former accounts/ } \\
\text { The bank staff are insufficient and the average management of accounts are too many } \\
\text { condition }\end{array}$ & Bank personnel setup \\
\hline Bank strength/bank lending capacity & Bank capital reserves \\
\hline The ability of the bank to generate revenue & Profitability of banks \\
\hline The difficult execution of the courts on bad loans. & $\begin{array}{l}\text { Policy } \\
\text { strength }\end{array}$ \\
\hline
\end{tabular}

\section{Associative Login}

In the previous section, the categories formed by researchers with open coding are all independent and scattered. Therefore, it is needed to analyze the relationship between various categories, summarize them into the main category and the sub-category, and reclassify them. The categories of the same kind are classified into a group called sub-category, and extract its categories as the main category. Therefore, associative login (second-order coding) is necessary. After the analysis and induction of the internal relations among various categories, the researchers extracted three main categories, namely economic factors, internal factors of banks and external interference factors, as shown in "Table III".
TABLE III. MAIN CATEGORIES AND SUB-CATEGORIES EXTRACTED FROM ASSOCIATION ENCODING

\begin{tabular}{|c|c|}
\hline Sub-categories & Main categories \\
\hline $\begin{array}{l}\text { Source structure of loan } \\
\text { repayment funds }\end{array}$ & \multirow{4}{*}{ Economic factors } \\
\hline Income level & \\
\hline Macroeconomic condition & \\
\hline Labor force destination & \\
\hline $\begin{array}{l}\text { Natural or man-made } \\
\text { emergency }\end{array}$ & \multirow{3}{*}{$\begin{array}{l}\text { External interference } \\
\text { factor }\end{array}$} \\
\hline Loan enforcement & \\
\hline $\begin{array}{l}\text { Subjective willingness to } \\
\text { repay }\end{array}$ & \\
\hline Bank personnel setup & \multirow{3}{*}{$\begin{array}{l}\text { Internal factors of the } \\
\text { bank }\end{array}$} \\
\hline Bank capital reserves & \\
\hline Profitability of banks & \\
\hline
\end{tabular}




\section{Core Login}

After conducting the open login and associative login, the next step is to find a Core concept category, so as to include the research results, reflect the logicality and hierarchy of categories, and establish the systematic connection between categories. Therefore the researchers conduct the third-order coding, which is core logging. Based on the comparison and analysis of the relationship between the categories for many times, the researchers extracted the core category that included all the research results: "factors and paths influencing the non-performing loan ratio of rural and commercial banks". The story line around this core category can be illustrated as follows: Whether the source of loan repayment funds of rural commercial bank customers is stable, whether the structure is reasonable, whether the income level of customers is high or low, the macroeconomic situation is good or low, the number of labor force is large or small, whether they are working or farming, all act as economic factors to affect the loan repayment ability of rural commercial bank customers, thus affecting the non-performing loans of rural commercial bank; whether the bank staff setting is reasonable or not, such as whether there are enough people in the bank to fully manage the lender and the condition of banking supervision, bank reserves, that is, whether the strength of the bank is strong or weak, whether the condition of bank profitability is high or low, namely the bank operation situation is good or bad, as banks internal factors affecting the bank's lending capacity, which affects bank non-performing loan ratio; in addition, some outside interference factors: natural or man-made emergencies, such as natural disasters caused lenders to failure, lenders suddenly unemployed, lenders' willingness to pay is not high, subjective malicious default, some institutions such as court for enforcement of loan defaults will not regularly, unexpected interfere with the normal recycling of bank loans, thus affecting the bank nonperforming loan ratio. Based on the above factors, the researchers constructed the influencing factors and influencing path model of non-performing loan ratio of rural commercial banks, as shown in "Fig. 1". 


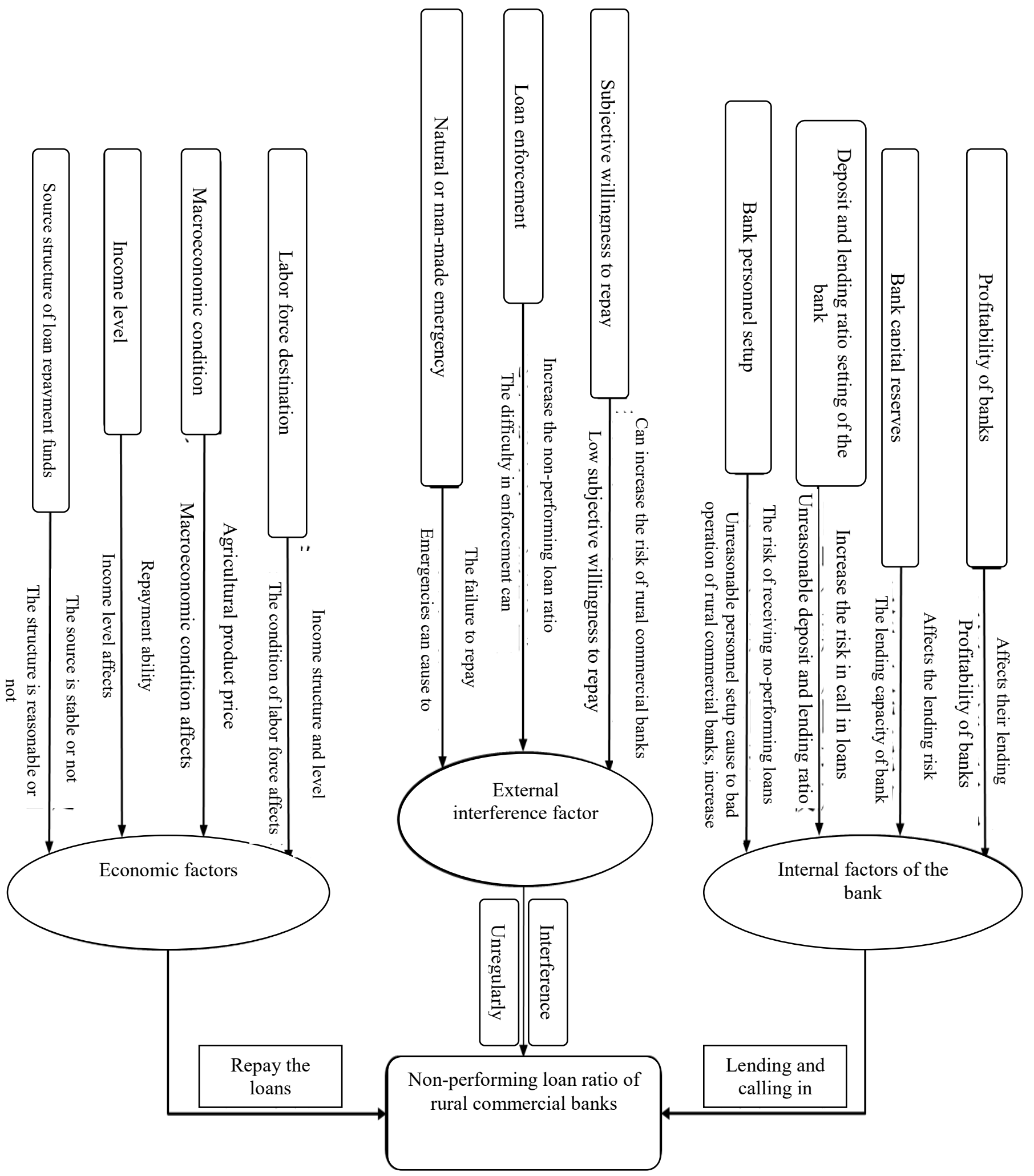

Fig. 1. Influencing factors and paths of non-performing loan ratio of agricultural commercial bank.

\section{MODEL DESCRIPTION}

Through three levels of coding, the researchers extracted that the non-performing loan ratio of rural commercial banks was affected by economic factors, internal factors and external interference factors. The first part of the economic factors include the source of loan repayment funds, income level, macroeconomic situation and labor force destination, 
which comprehensively affect the ability of the lender of rural commercial bank to repay the loan, and whether the customer has the ability to repay the loan also affects the non-performing loan ratio of rural commercial bank. The second part of the internal factors includes some sub-factors of bank staff setting, bank reserves and bank profitability for a couple of factors, which affect the bank's lending capacity, lending quotas (desire), strictness of lending censoring and loan recovery ability, effectiveness, possibility, which directly affects the bank non-performing loan ratio. And the third part of the interference factors including natural or man-made emergencies, repayment of loans enforcement, subjective intention that are difficult for banks to control, just as banks can't control an early frost, because they are unable to or can only take a big cost to expect that farmers cannot repay the loan on time because of sudden flood drought and crop failures.

\section{CONCLUSION}

\section{A. The Impact of Economic Factors on Loan Repayment}

It is suggested that rural and commercial banks should pay attention to the source and structure of loan repayment funds of customers when approving loans. They should not only take into account the salary statement, or written information of coinsurance members, such as the coinsurance loan of farmers, but also deeply investigate the income source structure and income level of the family, and comprehensively investigate the repayment ability of the lender and the loan team. As for the joint liability guarantee group, they should not lend to the group due to the high expectation of the solvency of one of its members, but should consider it as a whole and comprehensively examine its overall credibility level and loan repayment expectation. It is suggested that rural commercial banks should pay close attention to the current macroeconomic situation at all times. For example, when the economy goes down, they should be more cautious in lending. And for the loan approval of rural households, the market conditions of agricultural products should be investigated in advance to reduce the risk of nonperforming loans.

\section{B. The Impact of Internal Factors in the Bank}

In fact, this is the factor that rural and commercial banks have the best control over. Banks should carefully measure their strength and operating conditions, and determine lending strategies based on their own conditions. Proper risk appetite can lead to profits, but it can also lead to losses. Banks should balance their own conditions, adjust their business strategies and ensure profits with lower risks. As for the setting of bank personnel, it is suggested that rural commercial banks adjust their personnel structure according to their own characteristics. In areas and regions prone to non-performing loans, they should set up more staff and reduce the per capita household management. At the same time, attention should be paid to "professional skills" for household management personnel, who should be transferred their work in similar fields such as household management fields and regions, so as to prevent the efficiency reduction and other risks brought by the transition period of newcomers. At the same time the system management should be strengthened, by classifying reward and punishment to put an end to the bad atmosphere of "new staff ignoring the former accounts". At the same time, since they are commercial banks that emphasize policy, the government departments should strengthen supervision to prevent the preference for aggressive behaviors for profit of individual rural commercial banks.

\section{The Impact of External Interference Factors}

For external interference factors, which are irregular and most of them cannot be expected or the expected cost is quite large, the rural commercial banks should pay attention to preventing these factors. For natural disasters, such as drought, flood and so on, the observation of relevant institutions can be used to avoid the non-performing loan risk brought by customers who go to loan in the year of natural disasters. For the risk of sudden change in the lender's job, the first countermeasures for the impact of economic factors can also be used for reference. In the approval of loans, the income structure of the loan should be investigated, so as to avoid some risks to a certain extent. As for the court's execution, it also needs the policy support of the government and judicial departments. As for the subjective willingness of repayment of the repayment person, the credit standing of the lender should also be investigated before the approval of the loan. Not only the credit record of the repayment person, but also the character and risk evaluation of the repayment person should be comprehensively examined. This is relatively easy for the rural commercial banks that implement the loan of the Joint liability guarantee groups, because in the same village there are frequent contacts between people and people have deep understanding of each other, and it is easy to obtain the evaluation of the lender for staff sent for field visits. Moreover, they can obtain the evaluation of many lenders at one time, so the comprehensive evaluation has high practicability there. In addition, for the regions with bad ethos of default, on the one hand, rural commercial banks need to be vigilant and cautious in lending; on the other hand, the government and the public sector also need to strengthen local legal publicity and moral construction.

\section{REFERENCES}

[1] Brookes M, Dicks M, Pradhan M. An empirical model of mortgage arrears and repossessions [J]. Economic Modelling, 1994, 11(2):134144.

[2] Lopes P. Credit Card Debt and Default over the Life Cycle [J]. Journal of Money Credit \& Banking, 2008, 40(4):769-790.

[3] Demirgüçkunt A, Detragiache E. The Determinants of Banking Crises Evidence from Industrial and Developing Countries[J]. Policy Research Working Paper, 2016, 45(1):81-109.

[4] Xie Haidong, Hao Yibo. Measurement of macro external factors and regulatory policy orientation of non-performing loans under the new normal economy [J]. On Economic Problems, 2017(7):58-63. (in Chinese)

[5] Zhang Xiaoxi. Research on the relationship between economic cycle and asset quality of China's commercial banks [J]. Finance Economy, 2017(22):70-72. (in Chinese) 
[6] Zhuo Mingying. Research on influencing factors of non-performing loan ratio of commercial banks in China [D]. Huazhong University of Science and Technology, 2011. (in Chinese)

[7] Wang Guangwei, Tong Yuansong. Research on influencing factors of non-performing loan ratio of commercial banks in China - empirical analysis based on macro-quarterly data from 2005 to 2013 [J]. Journal of Shiyan Technical Institute, 2014, 27(3):50-54. (in Chinese)

[8] Berger A N, Deyoung R. Problem loans and cost efficiency in commercial banks [J]. Journal of Banking \& Finance, 1997, 21(6):849-870.

[9] Podpiera J, Weill L. Bad luck or bad management? Emerging banking market experience [J]. Journal of Financial Stability, 2008, 4(2):135148 .

[10] Belaid F. Loan quality determinants: evaluating the contribution of bank-specific variables, macroeconomic factors and firm level information[J]. Iheid Working Papers, 2014.

[11] Stolz S, Wedow M. Banks' regulatory capital buffer and the business cycle: Evidence for Germany $\Sigma[\mathrm{J}]$. Journal of Financial Stability, 2011, 7(2):98-110.

[12] Ayuso J, Pérez D, Saurina J. Are capital buffers pro-cyclical?: Evidence from Spanish panel data[J]. Journal of Financial Intermediation, 2004, 13(2):249-264.

[13] Lindquist G., 2004. Banks buffer capital: How important is risk? Journal of International Money and Finance, 2004, 23(3): 493-513.

[14] Xu Hui, Li Jian, Zhong Huibo. Research on the dynamic effects of bank cost efficiency and non-performing loans - application based on SFA measurement analysis [J]. Wuhan Finance Monthly, 2013(2):11-14. (in Chinese)

[15] Fan Yong. Research on influencing factors of non-performing loan ratio of commercial Banks [D]. Chongqing university, 2015. (in Chinese)

[16] Chen Weiping, Feng Zongxian. Research on productivity growth and convergence of China's rural commercial Banks under the constraint of non-performing loans [J]. Journal of Business Economics, 2015(1):71-79.(in Chinese)

[17] Li Jing, Zhu Chengliang, Zheng Shilin. Performance of rural credit cooperatives under the constraint of non-performing loans evidence from 86 counties (districts) in 8 cities of shaanxi province [J]. Chinese Rural Economy, 2015(11):63-76.(in Chinese)

[18] Huang Huichun, Cao Qing, Li Qucheng. Analysis on the reform efficiency of rural credit cooperatives under the constraint of nonperforming loans - based on SBM directional distance function [J]. Journal of Agrotechnical, 2014(10):86-94. (in Chinese)

[19] Geng Rui, Zhang Guangwen, Gao Lan. Analysis of influencing factors of rural credit cooperatives' non-performing loans - based on the time series model [J]. China Journal of Commerce, 2014(6):72-74. (in Chinese)

[20] Chen Weiping, Feng Zongxian. Research on productivity growth and convergence of China's rural commercial Banks under the constraint of non-performing loans [J]. Journal of Business Economics, 2015(1):71-79. (in Chinese)

[21] Li Qing. Research on operational efficiency and influencing factors of rural commercial Banks based on DEA model - a case study of Yongzhou, Hunan [J]. Financial Theory \& Practice, 2016(3):45-48. (in Chinese)

[22] Ye Chusheng, Zou Xin. Analysis on peasant household repayment behavior during the loan period - an empirical study of Cox model based on rural commercial credit micro data $[\mathrm{J}]$. Hubei social sciences, 2016(3):89-96. (in Chinese)

[23] Cui Jun, Li Hongbing, Shi Xian. NPL disposal experience of rural commercial bank of China - a case study of Beijing rural commercial bank of China [J]. The Banker, 2016(8):22-24.(in Chinese)

[24] Huang Pingjian. Influence of non-performing loans on the business development of rural commercial Banks in county and countermeasures - a case study of Cangnan rural commercial bank [J]. China Economist, 2017(6):147-148. (in Chinese) 